\title{
THE APPLICATION OF PEST ANALYSIS BASED ON EBRD AND IBRD METHODOLOGY
}

\author{
Halík, J.
}

This paper discusses the possible applications of PEST analysis with the use of methodology and data from The European Bank for Reconstruction and Development, and The International Bank for Reconstruction and Development/ World Bank/International Finance Corporation. A practical example shows how to use the models when setting up a logistics service company in selected Central/Eastern European markets. The combination of PEST and EBRD/ IBRD reports is seen as a viable tool for measuring market potential, its growth or decline, as well as the attractiveness, business opportunity and suitability of access into these countries.

JEL classification: M21

\section{Introduction}

PEST analysis is a widely used tool for measuring market potential, i.e. its growth or decline, attractiveness, business opportunity and suitability of access. PEST is an acronym for Political, Economic, Social and Technological factors, i.e. those which are being used to assess the market for a business or organizational unit. Like SWOT analysis, Porter's 5 Forces analysis, Ansoff analysis, BCG Growth-Share Matrix, Porter's Generic Strategies, Scenario Planning, and Value Chain Analysis, PEST can be used to review a strategy or position, direction of a company or a marketing proposition. PEST is a good subject for workshop sessions and brainstorming meetings. The results of the PEST analysis are used for business and strategic planning, marketing planning, business and product development and research reports.

In analyzing a company's external environment, it is important to identify the factors that are likely to influence the organization's supply and demand levels and its costs (Kotter and Schlesinger, 1979). The radical and ongoing changes occurring in the marketplace create an uncertain environment and have an impact on the functioning of the whole company (Tsiakkiros, 2002). PEST analysis is a methodology that helps us to categorize the influences in the political, economic, social and technological environments. Sometimes two additional factors, environmental and legal, are added to make a PESTEL analysis. Other variations include PESTLE, PESTEL, PESTLIED, STEEPLE(D), and SLEPT analysis, ${ }^{1}$ in accordance to considering ecological, environmental, ethical, demographic and legal factors. The analysis examines the impact of each of these factors (and their interplay with each other) on the business. The results can then be used to take advantage of opportunities and to make contingency plans for threats when preparing business and strategic plans (Byars, 1991). PEST also ensures that a company's performance is aligned positively with the forces that are affecting the business environment (Porter, 1985). PEST is useful when a company decides to enter its business operations into new markets and new countries. The use of PEST, helps to break free of unconscious assumptions, and helps to effectively adapt to the realities of the new environment.

The process of assembling the four basic perspectives of the PEST analysis always reflects the company's current

1 PESTLE/PESTEL: Political, Economic, Sociological, Technological, Legal, Environmental; PESTLIED: Political, Economic, Social, Technological, Legal, International, Environmental, Demographic; STEEPLE(D): Social/ Demographic, Technological, Economic, Environmental, Political, Legal, Ethical; and SLEPT: Social, Legal, Economic, Political, Technological. 
position in the marketplace within given environmental circumstances. There is no general rule about which factors are more or less important. Such a task requires sufficient managerial skills and business experience. Some examples of topics might be the following: Political - which includes legal and regulatory issues - elections, employment law, consumer protection, environmental regulations, industry-specific regulations, competitive regulations, inter-country relationships/attitudes, war, terrorism, political trends, governmental leadership, taxes, government structures, etc. Economic - economic growth trends across various countries, taxation, government spending levels, disposable income, level of unemployment, exchange rates, tariffs, inflation, consumer confidence index, import/export ratios, production levels, etc. Social - demographics (age, gender, race, family size, etc.), lifestyle changes, population shifts, education, trends, fads, diversity, immigration/ emigration, health, living standards, housing trends, fashion, attitudes to work, leisure activities, occupations, earning capacity, etc. Technological - inventions, new discoveries, research, energy uses/sources/fuels, communications, rates of obsolescence, health (pharmaceutical, equipment, etc.), manufacturing advances, information technology, internet, transportation, bio-tech, genetics, agri-tech, waste removal/ recycling, and so on. The incorporation of the four perspectives gives a logical structure, provides clear presentation for further discussions and proactive decision making.

\section{The EBRD Methodology Applicable for PEST Analysis}

The European Bank for Reconstruction and Development collects and disseminates a number of time series data. These data are collected for all countries of operations and are published annually in the Transition Report, which is a unique source of information on the developments in Central and Eastern Europe and the Commonwealth of Independent States (CIS). Drawing on the EBRD`s extensive experience as an investor in the region, the Report offers comprehensive analysis of the transition to becoming a market economy and macroeconomic performance. Country-by-country assessments comprise macroeconomic tables, including output and expenditure and foreign direct investment. They also provide key data on liberalization, stabilization, privatization, enterprise reform, infrastructure, financial institutions and social reform. The sample economic developments in EBRD`s countries of operations are examined in a series of country assessments and economic tables looking at GDP growth, inflation and other economic factors (EBRD, 2012). The first series includes selected macroeconomic indicators that provide basic macroeconomic statistics in key areas of the economy: output, employment, prices and wages, government sector, monetary sector, interest and exchange rates and external sector.

The second series provides forecasts of the main macroeconomic indicators for transition countries. The appendix No. 1 shows forecasts for the years 2011-12.

Structural change indicators, which are in the third series, provide a quantitative foundation for analyzing the progress in transition. The tables contain structural and institutional indicators in the areas of enterprises, markets and trade, financial sector and infrastructure.

In the fourth series, EBRD assesses progress in transition through a set of transition indicators. These have been used to track reform developments in all countries of operation since the beginning of transition. Progress is measured against the standards of industrialized market economies, while recognizing that there is neither a "pure" market economy nor a unique end-point for transition. Assessments are made in nine areas: large scale privatization, small scale privatization, governance and enterprise restructuring, price liberalization, trade and foreign exchange system, competition policy, banking reform and interest rate liberalization, securities markets and non-bank financial institutions, and infrastructure.

The fifth series of data helps to describe progress in transition. Transition developments snapshots highlight qualitative or institutional developments in the areas of liberalisation and privatisation, the business environment and competition, infrastructure, the financial sector and social reform.

\section{The IBRD Methodology Applicable for PEST Analysis}

The International Bank for Reconstruction and Development, The World Bank and the International Finance Corporation have published four series of annual reports investigating the regulations that enhance business activity and those that constrain it. The sample one - Doing Business 2012 in a More Transparent World - presents quantitative indicators on business regulations and the protection of property rights that can be compared across 175 economies - from Afghanistan to Zimbabwe - and over time. Regulations affecting 10 areas of everyday business are measured: starting a business, dealing with licenses, employing workers, registering property, getting credit, protecting investors, paying taxes, trading across borders, enforcing contracts and closing a business. The indicators are used to analyze economic outcomes and identify what reforms have worked, where and why (World Bank and IBRD, 2012).

The appendix No. 2 contents the complete set of indicators over six a selected Eastern and Central European country - The Czech Republic. The data can be used for construction of a PEST analysis for selected territories in the world 
Figure 1: Country portfolio according to GDP and GDP/Capita

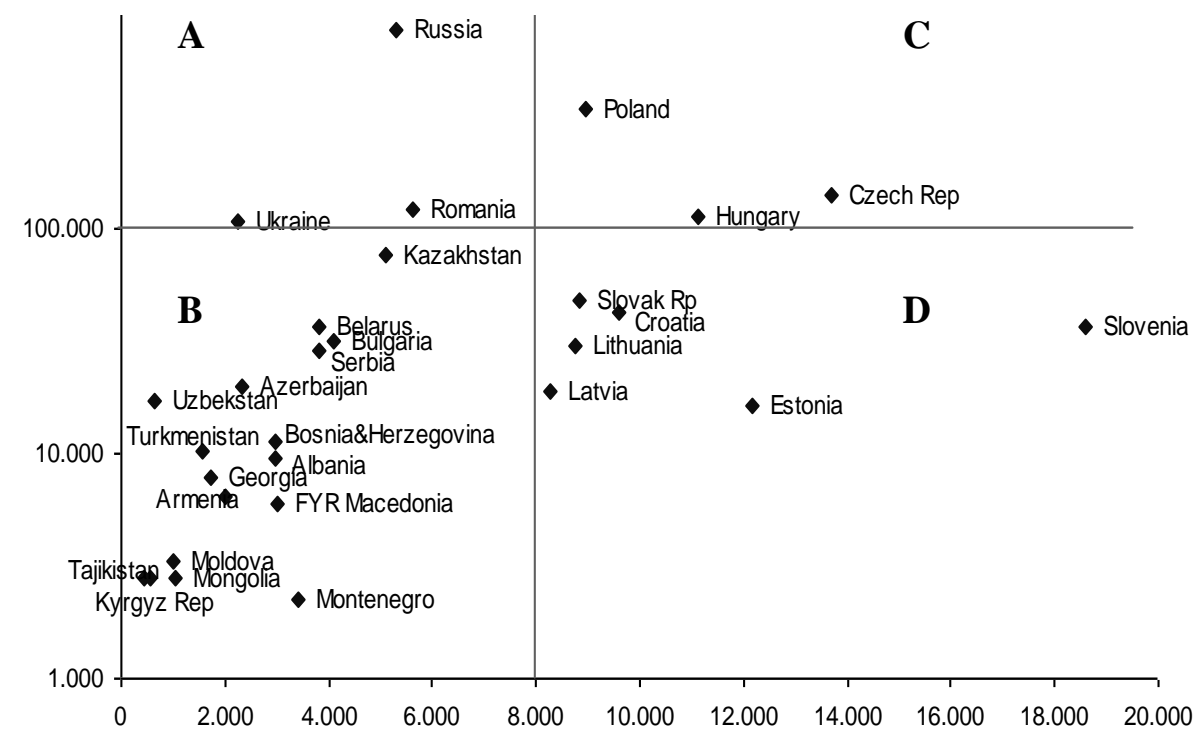

Source: EBRD (2012)

and allow straight comparisons of very important practical indicators of conducting business in different countries. They document the degree of regulation, such as the number of procedures to start a business or register commercial property. They gauge regulatory outcomes, such as the time and cost to enforce a contract, go through bankruptcy or trade across borders. They also measure the extent of legal protection of property, for example, the protection of investors against looting by company directors or the scope of assets that can be used as collateral according to secured transactions laws. They measure the flexibility of employment regulation. Finally, a set of indicators document the tax burden on businesses.

In the following text, an example for practical use of both EBRD and IBRD methodologies when assembling PEST analysis will be presented.

\section{Case Study: The Practical Application of PEST in a Company's Set-Up}

TransLog International Ltd. is a logistics service provider for the food industry. TransLog specializes in shipping perishable and frozen foods from the manufacturer to importers in other parts of the world. TransLog also distributes these goods domestically as a service provider for retail chains. The company has developed a unique system of tracking shipments and providing approved records, which show that the legal hygiene requirements are met at all times. These records are essential for retailers as they have to prove to health authorities that the goods are transported at a maximum temperature of $+4^{\circ} \mathrm{C}$ for perishable and $-18^{\circ} \mathrm{C}$ for deep frozen produce for example. TransLog has developed special patented cooling cabins for trucks, trains, planes and ships that are self-regulating and are able to maintain constant temperatures in each segment of the cabin and measure the temperature of the goods constantly. Furthermore, TransLog has established a sophisticated dispatching and physical distribution system that allows TransLog to ship goods faster than other logistics providers. TransLog is a market leader in food logistics services in Western Europe, the US, Asia, and the Americas as well as in South Africa and Australia. Over the past 20 years, TransLog has enjoyed constant growth in operations as international trade with fresh and frozen food has steadily increased. The developed markets are slowly entering stagnant phases with only little future growth potential. TransLog has no competitor that offers such comprehensive services and such an extended logistics network for food.

TransLog is now considering expanding into former Eastern Bloc countries as rising standards of living increase the demand for high quality and more exotic food. Furthermore, increased trade among EU-Member states and countries neighboring with the EU, especially Russia and CIS countries, shows higher demands for chilled transportation services. TransLog sees great opportunities for further growth expanding into Central/Eastern European regions.

TransLog's logistical services are closely related to the standard of living in regions and countries. Supermarkets and retailers demanding TransLog's services are usually found in those countries where people are able to spend sufficient amounts on high quality food. A GDP per capita of at least 
Figure 2: GDP - Growth and Inflation Forecasts for 2007-2012

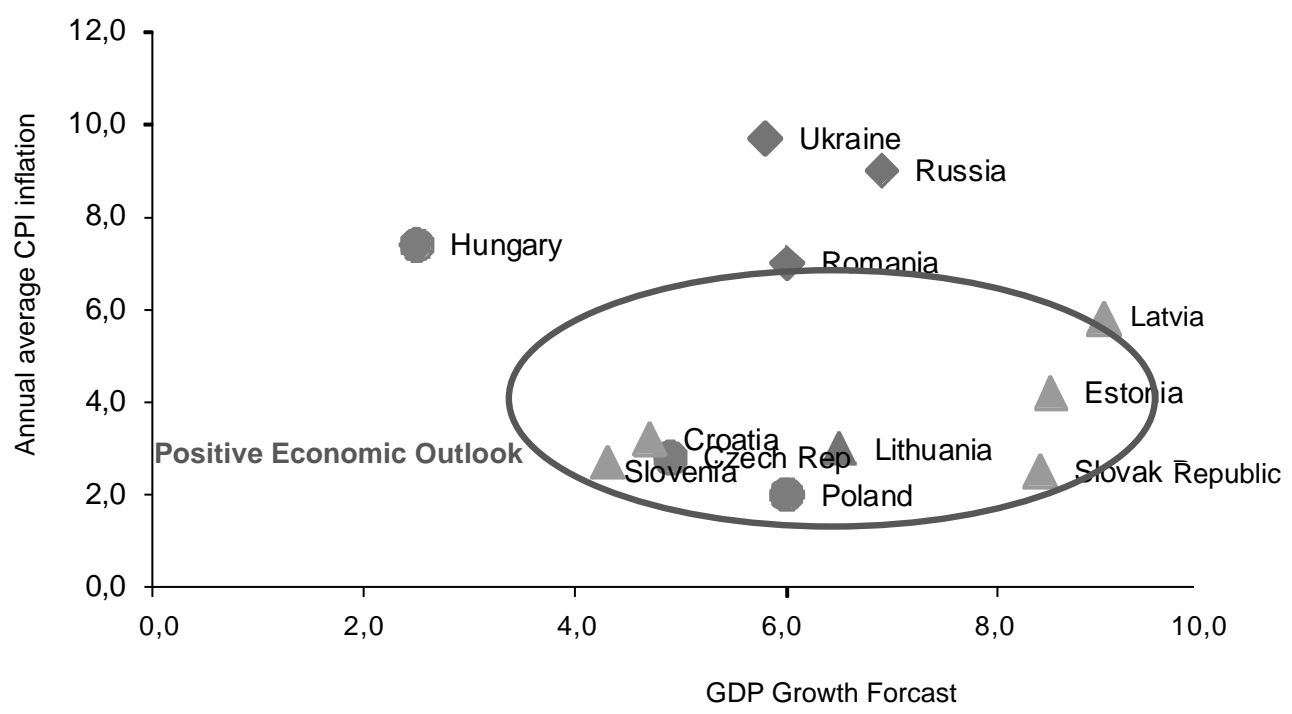

Source: EBRD (2012)

$\$ 8,000$ is seen as a minimum requirement. However to justify direct investments - especially into domestic distribution services - the country should have a certain market size. A total GDP of $\$ 100$ billion is generally regarded as the cut-off line. TransLog also specializes in shipping bulk loads across borders. So transportation to major import and export or transition points is also important. Countries with large exports and/or imports of fresh produce are targets for investments.

TransLog's business needs relatively high investments for infrastructure such as warehouses, trucks and communication and IT. These investments are highly specific and are long lived assets. Therefore, TransLog's requirements for protecting their foreign investments and for political stability in targeted markets are high.

Furthermore, shipments across borders are an essential part of TransLog's services. Therefore speed and certainty in customs procedures are relevant criteria for targeting a region or country as well as positive macro-economic developments. TransLog's pre-selection process consists of two independent levels - market size and wealth as well as major import/ export volumes. A third level takes a closer look at markets pre-selected by the former levels. This level examines the general business environment of the pre-selected countries. The selection of potential markets on the first level is derived from the EBRD Transition Reports 2007-2012. From all Eastern, Southern and Central European countries as well as the Commonwealth of Independent States, all those that are insufficient in size (GDP $<\$ 100$ billions) and that display a GDP per capita of less than $\$ 8,000$ are eliminated from the long list. Figure 1 and Figure 2 show the comparisons.

The results show that Poland, the Czech Republic and Hungary are preliminary candidates for direct investments of TransLog. Estonia, Lithuania and Latvia could be grouped as one potential region for direct investments. The Slovak Republic could be analyzed in conjunction with the Czech Republic. Slovenia and Croatia could also be grouped as a potential region. Russia needs to be analyzed separately as it is extremely heterogeneous in terms of distribution of wealth and regional concentration of business. In terms of economic development, the Slovak and Czech Republics, Estonia, and Poland indicate above EU average GDP growth rates and relatively low inflation. This indicates an increase in wealth leading to higher demand for exotic and imported foods.

The second level of selection considers current volumes of food imported and exported and their trends. Food Exports from the EU to Russia increased substantially over the period. Moscow is the main region in Russia where imports go. Poland is the biggest trading country of the new EU-members; it also has the highest increase in exports. Same large increases were also recorded for the Czech Republic and Hungary. The most promising countries for direct investments from the market perspective are Poland, the Czech Republic, Hungary and Russia - see Figure 3.

The Czech Republic could also function as a steppingstone into Slovakia. The Baltic States together are not quite large enough in terms of volume, but could serve as a hub into Russia, justifying direct investments. TransLog's business has three main criteria, which are essential for doing 
Figure 3: Import/Export of Food Between CIS and Central European EU-Member States

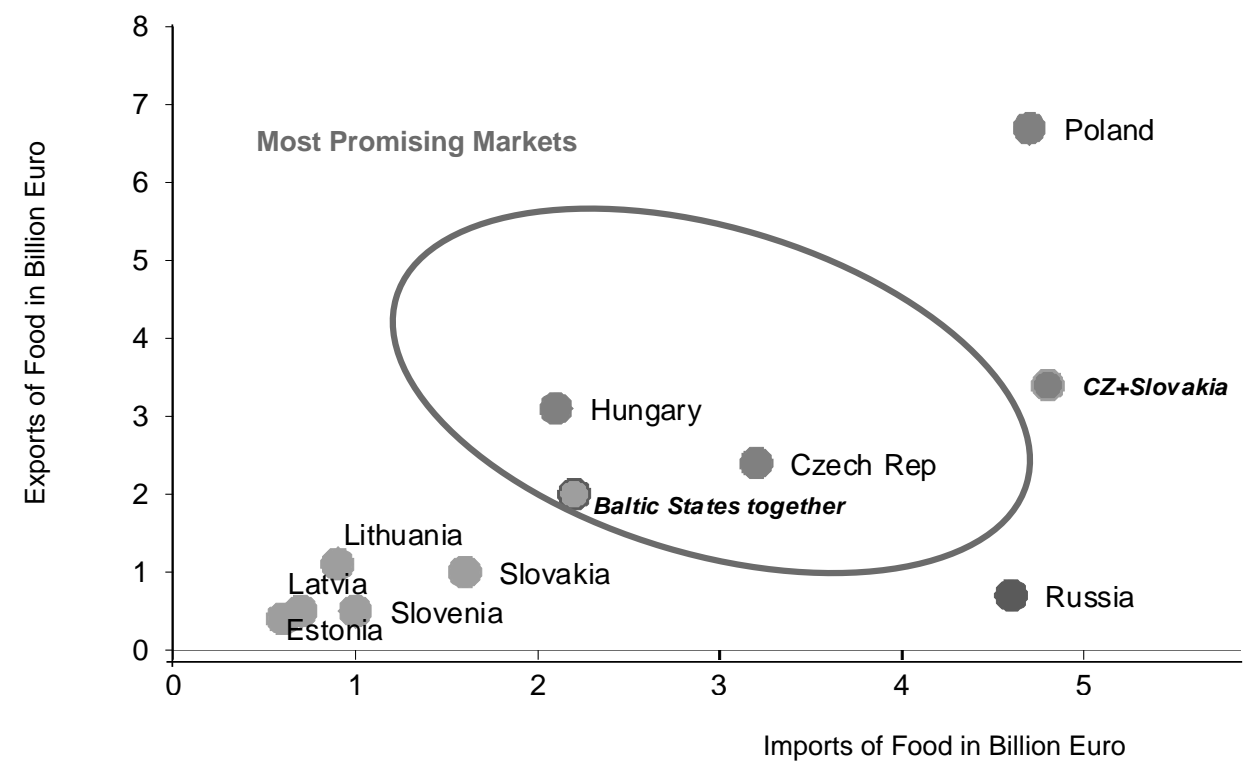

Source: Eurostat, 2007-2012.

business: conditions for trading across borders, registering property, and employing workers. Trading across borders and associated costs for bureaucracy (fees, charges storage in customs etc.) are important factors for TransLog as they influence demand for imported food. The higher the costs the less attractive international trade gets for food - limiting the potential for food logistics. It also influences the kind of products traded. Export and import fees in the Czech Republic and Hungary are the lowest amongst the selected set. Poland and Russia charge almost 2.5 to 3 times the fees that the Czech Republic charges - see Figure 4.

Poland and the Czech Republic display sufficient wealth and market size and trade food in relatively high volumes. Both countries show promising developments in their GDP at low inflation rates. Russia mainly imports food - most of which is destined for Moscow. Moscow therefore represents high specific volumes concentrated on a relatively small area. Demand for high quality food in Moscow is less dependent on inflation of the local currency, as the segment of society that consumes these products is less concerned about prices in this area. Hungary - although attractive in terms of market size, wealth and import/export volumes - is not an attractive target market for TransLog as the extremely high cost of registering property prohibits any direct investments. Furthermore, the high inflation rate and low GDP growth rate make large investments too risky in the near future. The Czech Republic and Poland are both EU-member states. In most cases, their legal systems are compliant with EU standards. The only limitation of importance is the tradability of land. Foreigners are not allowed to acquire property. As it is TransLog's policy to always found subsidiaries in its markets, there is no problem with this limitation. Current deficiencies in transaction laws are also of lesser importance as TransLog does business solely under international law.

\section{Results and Discussion}

The major contribution of this research is the formulation and presentation of a possible methodology of data-gathering through PEST analysis, while taking advantage of EBRD and IBRD Country Reports.

In our paper, Poland, Russia and the Czech Republic are the suggested countries for direct investment. Poland and the Czech Republic display sufficient wealth and market size and trade food in relatively high volumes. Both countries show promising developments in their GDP at low inflation rates. Russia mainly imports food - most of which is destined for Moscow. Moscow therefore represents high specific volumes concentrated on a relatively small area. Demand for high quality food in Moscow is less dependent on inflation of the local currency, as the segment of society that consumes these products is less concerned about prices in this area. Hungary, although attractive in terms of market size, wealth and import/export volumes is not an attractive target market for TransLog as the extremely high cost of registering property prohibits any direct investments. Furthermore, the high inflation rate and low GDP growth rate make large investments too risky in the near future. The 
Figure 4: Bureaucracy Costs of International Trade

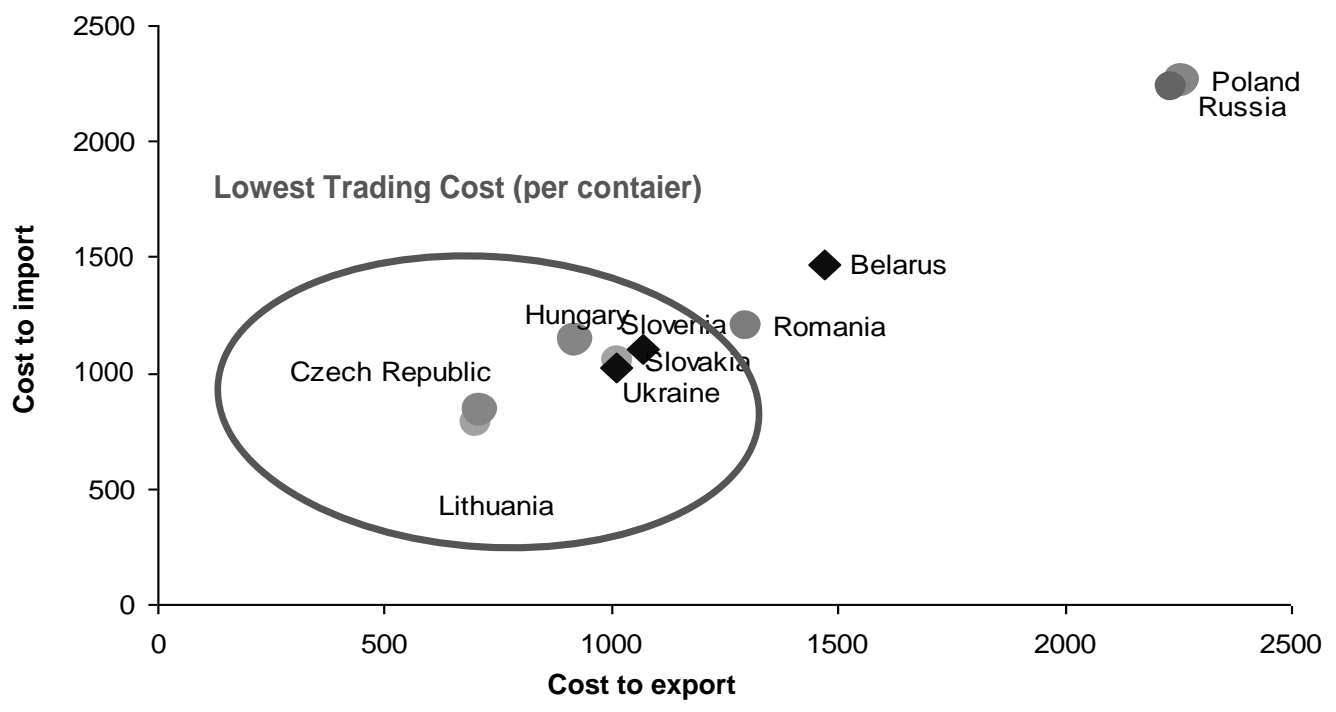

Source: World Bank, IBRD (2012).

Czech Republic and Poland are both EU-member states; their legal systems are, in most cases, compliant with EU standards. The only limitation of importance is the tradability of land; foreigners are not allowed to acquire property. As it is TransLog's policy to always found subsidiaries in its markets, there is no problem with this limitation. Current deficiencies in transaction laws are also of lesser importance as TransLog does business solely under international law. Any legal suits are always brought in front of a US court.

Managerial Implications

The form of a case study can be applied in similar practical business situations. The text is namely aimed to small and medium enterprises that intend to expand abroad. PEST analysis usually serves as an essential part of business planning.

\section{References}

Byars, L. (1991). Strategic Management, Formulation and Implementation: Concepts and Cases. New York: HarperCollins.

EBRD (2012). Transition Report 2012, (accessed December 21), [available at http://www.ebrd.com/pages/research/ publications/flagships/transition.shtml]

EBRD (2012a). Transition Development Snapshots, (accessed December 19), [available at http://www.ebrd.com/ downloads/research/economics/macrodata/sib.xls]
EBRD (2012b). Forecasts, macro data, transition indicators, (accessed December 19), [available at http://www.ebrd. com/pages/research/economics/data/macro.shtml].

Kotler, P. (1998). Marketing Management - Analysis, Planning, Implementation, and Control. Englewood Cliffs: Prentice-Hall.

Kotter, J., Schlesinger, L. (1979). Choosing strategies for change. Harvard Business Review, 57: 106-114.

Porter, M. (1985). Competitive Advantage. New York: Free Press.

Tsiakkiros, A. (2002) Strategic planning and education: The case of Cyprus. The International Journal of Educational Management, 16(1): 6-17.

World Bank, IBRD (2012): Doing Business 2012 in a More Transparent World. Washington: The International Bank for Reconstruction and Development / The World Bank.

Author

Ing. Jaroslav Halík, MBA, Ph.D. Senior Lecturer

University of Economics, Prague Department of International Trade, Faculty of International Relations W. Churchill Sq. 4, 13067 Prague 3, Czech Republic halik@vse.cz 
Appendix No. 1: Forecasts of Macroeconomic Indicators for Transition Countries in 2012

\begin{tabular}{|c|c|c|c|c|c|c|}
\hline & \multirow{2}{*}{\multicolumn{4}{|c|}{ GDP Growth (average) }} & \multirow{2}{*}{\multicolumn{2}{|c|}{$\frac{\text { Inflation (average) }}{\text { (year over year percent change) }}$}} \\
\hline & & & & & & \\
\hline & \multirow[b]{2}{*}{2010} & \multirow[b]{2}{*}{2011} & \multicolumn{2}{|c|}{ Forecast $1 /$} & & Forecast $1 /$ \\
\hline & & & 2012 & 2013 & 2011 & 2012 \\
\hline \multicolumn{7}{|l|}{ Central Europe and Baltics } \\
\hline Croatia & $-1,4$ & 0,0 & $-1,9$ & 1,2 & 2,3 & 3,2 \\
\hline Estonia & 3,3 & 8,3 & 2,3 & 2,5 & 5,1 & 4,3 \\
\hline Hungary & 1,3 & 1,6 & $-1,5$ & 0,4 & 3,9 & 5,5 \\
\hline Latvia & $-0,9$ & 5,5 & 4,2 & 2,7 & 4,2 & 2,4 \\
\hline Lithuania & 1,5 & 5,9 & 2,7 & 2,4 & 4,1 & 3,0 \\
\hline Poland & 3,9 & 4,3 & 2,5 & 2,2 & 3,9 & 4,0 \\
\hline Slovak Republic & 4,2 & 3,3 & 2,7 & 2,3 & 4,1 & 4,0 \\
\hline Slovenia & 1,2 & 0,6 & $-2,5$ & $-2,0$ & 2,1 & 2,5 \\
\hline \multicolumn{7}{|l|}{ South-Eastern Europe } \\
\hline Albania & 3,5 & 3,1 & 0,6 & 1,3 & 3,5 & 2,1 \\
\hline Bosnia and Herzegovina & 0,7 & 1,3 & 0,1 & 0,4 & 3,7 & 1,9 \\
\hline Bulgaria & 0,4 & 1,7 & 1,2 & 1,7 & 3,4 & 2,8 \\
\hline FYR Macedonia & 2,9 & 2,9 & 0,3 & 2,0 & 3,9 & 3,5 \\
\hline Montenegro & 2,5 & 3,2 & 0,3 & 0,8 & 2,9 & 3,2 \\
\hline Romania & $-1,7$ & 2,5 & 0,5 & 1,9 & 5,8 & 3,5 \\
\hline Serbia & 1,0 & 1,6 & $-0,7$ & 1,1 & 11,1 & 7,1 \\
\hline \multicolumn{7}{|c|}{ Eastern Europe and the Caucasus } \\
\hline Armenia & 2,2 & 4,6 & 5,0 & 4,0 & 7,7 & 3,0 \\
\hline Azerbaijan & 5,0 & 0,1 & 2,0 & 3,0 & 8,5 & 1,5 \\
\hline Belarus & 7,7 & 5,3 & 5,5 & 2,5 & 52,9 & 60,0 \\
\hline Georgia & 6,3 & 6,9 & 6,5 & 5,0 & 8,5 & 0,0 \\
\hline Moldova & 7,1 & 6,4 & 1,0 & 3,5 & 7,2 & 4,0 \\
\hline Ukraine & 4,1 & 5,2 & 1,0 & 2,5 & 7,7 & 1,5 \\
\hline Turkey & 9,2 & 8,5 & 3,0 & 3,7 & 6,5 & 9,1 \\
\hline Russia & 4,3 & 4,3 & 3,2 & 3,3 & 8,4 & 5,1 \\
\hline \multicolumn{7}{|l|}{ Central Asia } \\
\hline Kazakhstan & 7,3 & 7,5 & 5,5 & 6,0 & 8,4 & 5,3 \\
\hline Kyrgyz Republic & $-0,5$ & 5,7 & $-1,1$ & 7,0 & 16,6 & 2,7 \\
\hline Mongolia & 6,4 & 17,5 & 11,5 & 16,0 & 9,1 & 15,0 \\
\hline Tajikistan & 6,5 & 7,4 & 6,0 & 5,0 & 12,5 & 6,5 \\
\hline Turkmenistan & 9,2 & 14,7 & 10,0 & 10,0 & 5,8 & 6,0 \\
\hline Uzbekistan & 8,5 & 8,3 & 7,5 & 7,0 & 12,8 & 10,0 \\
\hline \multicolumn{7}{|c|}{ Southern and Eastern Mediterranean } \\
\hline Egypt & 5,5 & $-0,6$ & 3,2 & 3,8 & 10,1 & 8,0 \\
\hline Jordan & 2,3 & 2,6 & 2,6 & 3,0 & 4,4 & 5,0 \\
\hline Morocco & 3,6 & 5,0 & 2,3 & 4,5 & 0,9 & 1,9 \\
\hline Tunisia & 3,2 & $-1,5$ & 2,4 & 3,0 & 3,5 & 5,3 \\
\hline
\end{tabular}

1/ As of October 12, 2012. 


\section{Appendix No. 2: IBRD - Doing Business Country Indicators in 2012}

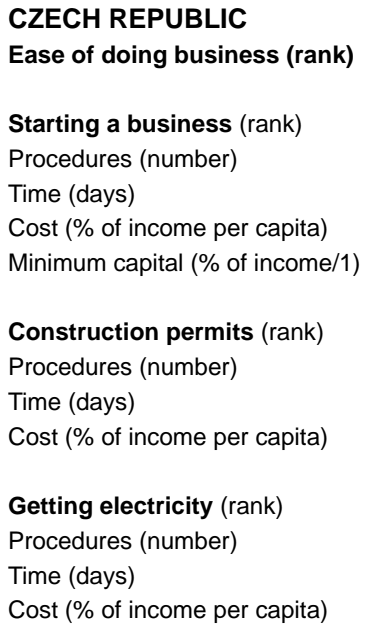

\author{
OECD high income \\ High income
}

Registering property (rank)

Procedures (number)

Time (days)

Cost (\% of property value)

Getting credit (rank)

Strength of legal rights index (0-10)

Depth of credit info index (0-6)

Public registry (\% of adults)

Private bureau (\% of adults)

Protecting investors (rank)

Extent of disclosure index (0-10)

Extent of director liability (0-10)

Ease of shareholder suits $(0-10)$

Investor protection (0-10)

Paying taxes (rank)

Payments (number per year)

Time (hours per year)

Total tax rate (\% of profi t)
GNI per capita (US\$)

Population (m)

Trading across borders (rank)

Documents to export (number)

Time to export (days)

Cost to export (US\$ per container)

Documents to import (number)

Time to import (days)

Cost to import (US\$ per container)

Enforcing contracts (rank)

Procedures (number)

Time (days)

Cost (\% of claim)

Resolving insolvency (rank)

Time (years)

Cost (\% of estate)

Recovery rate (cents on the dollar)
17,870

10.5

70

17

1,060

1,165

Source: IBRD - Doing Business 2012 in More Transparent World. 